\title{
大規模浸水における小河川と下水道の 影響に関する数值解析的検討
}

\author{
武田 誠 1 ・ケンインヒ 2 ・村瀬将隆 2 -中島勇介 2 ・川池健司 3 - 松尾直規 4 \\ 1 正会員 博士(工学) 中部大学教授 工学部都市建設工学科（广487-8501 愛知県春日井市松本町 1200） \\ E-mail:mtakeda@isc.chubu.ac.jp \\ 2 学生会員 中部大学大学院工学研究科建設工学専攻（广487-8501 愛知県春日井市松本町 1200 ) \\ 3 正会員 博士(工学) 京都大学准教授 防災研究所（ \\ 4フェロー 工学博士 中部大学教授 工学部都市建設工学科（テ487-8501 愛知県春日井市松本町 1200)
}

\begin{abstract}
大規模浸水の計算の場合, 計算領域も大きくなるので, 計算量を抑えるために計算格子幅は極端に小さ くできない。一般には, 計算格子幅は $50 \mathrm{~m}$ 程度（最近では $25 \mathrm{~m}$ 程度）が採用されている。このような場 合，小河川の水理は無視（河川内は満水と仮定）している場合があり, さらに都市の中の下水道施設も影 響が小さいと仮定して無視される場合が多い，本研究では，大規模浸水の計算に対して，小河川および下 水道システムを取り扱い，その影響を数值解析的に検討寸る，それらの配置に依存寸るであろうが，本研 究の場合, 小河川や下水道システムの影響は, 破堤箇所付近では大きな差が生じなかったが, 氾濫水の拡 がりと浸水の低下において影響が生じた．また，地下鉄などの浸水の面からも，大きな差は生じておらず， 大規模な浸水深の状況は大きく変わらない結果となったことが考えられる.
\end{abstract}

Key Words: Large scal inundation due to dike break, Urban area, small river, sewer system, subway

\section{1. はじめに}

近年，局地的豪雨や洪水時の破堤による浸水被害が多 く見られる. 2016年 8 月 31 日には, 台風 10 号の影響に よって，北海道南富良野町に空知川の堤防決壊による氾 濫や市街地への浸水が相次ぎ, 200 人が孤立状態になっ $た^{1)}$ 。また, 2011 年 9 月 19 日台風 15 号の影響によって 名古屋市のそばを流れる庄内川の水位が汇濫危険水位を 超え名古屋市志段味地区では浸水被害が生じたが，大規 模な破堤災害は生じなかった。 しかし，このような大規 模な洪水は近年多数報告されており，堤防決壊が発生し， 大都市において甚大な浸水被害が生じる可能性は否定で きない.

大都市には，氾濫水の挙動に影響を与える小河川，下 水道システム, 地下鉄や地下街などの地下空間施設が存 在する. 仮に大規模な洪水汇濫が生じた場合, 汇濫水は これらの施設を伝って，拡がることが考えられる．しか し, 大規模な浸水被害を対象とする場合, 計算領域や計 算時間が多大となること, 全体の浸水現象に対して相対 的に影響が小さいと考えらることなどから，小河川や下 水道システムの影響は無視されて計算される事例も多い.
しかし，豪雨による内水氾濫の再現計算では，小河川や 下水道システムの影響が解析結果に大きく反映されるの で，その水理を解く物理モデルが開発されている．例え ば，関根ら ${ }^{2)}$ は下水道を考慮した解析モデルを用いて， 東京における荒川破堤による大規模浸水を検討している. また，石垣ら ${ }^{3)}$ はなんば駅前の地下空間施設を対象に, 津波や洪水を想定した浸水解析を行っている. 本研究も 名古屋における大規模浸水を対象とした. 本研究の先行 研究として, 地下鉄や地下街を考慮した名古屋の大規模 浸水の検討がある 4,5. これらの研究では, 都市域の複 杂倠な地下施設を考慮している点で特徽があるが，陸域の 汇濫解析では, 小河川を非計算領域としており, 下水道 システムの効果は無視して計算を行っている. 検討を進 める中で, 小河川や下水道システムの取り扱いによる計 算結果の差が課題として残った. 大きな差が生じなけれ ば無視しても良いであろうし, 大きな差が生じる場合に は, 小河川や下水道システムを含めて検討寸る必要があ る. 本研究では, 地下鉄や地下街を考慮し, 小河川を堤 防高までの地艋高格子（河川は満水と仮定）とする解析 を基礎として，そのモデルに小河川と下水道システムに おける汇濫水の挙動のモデル化を加えて解析を行い, 大 
規模浸水に対する小河川や下水道システムの影響につい て検討する.

\section{2. 解析の概要}

本研究は洪水流を 1 次元不定流モデル，地表面氾濫流 をデカルト座標の平面 2 次元不定流モデルで解析し，互 いを越流公式で接続している．また，地下空間（地下街 および地下鉄駅）を一つのボックスとして捉え，地表面 からの流入・流出を考慮し, 地下鉄線路への流入・流出 を考慮して水量の収支を計算している。 また，地下鉄線 路の水の挙動はスロットモデルを考慮した 1 次元不定流 モデルで表現している．なお，紙面の都合上，詳細は武 田・西田ら 5)を参照されたい. 計算領域を図-1 に示す. 地表面汇濫域の計算では $25 \mathrm{~m}$ 幅の計算格子を用い，河 川格子には周辺の地盤高の最大值を与えている.

\section{（1）小河川のモデル化}

小河川の水理を考慮する場合，各小河川の断面データ に基づき，汇濫格子の地盤高を下げて河床高とし，荒子 川, 中川運河, 堀川, 新堀川を表現し, 水の挙動は平面 2 次元不定流モデルで解析した. したがって，小河川格 子では氾濫水の流入後小河川格子を流下し, 越水が生じ た場合には，汇濫域に水が拡がることになる．取り扱っ た多くの河川は掘り込み河川であり，堤防が存在してい ない. 堀川下流部には堤防が存在するので, 堤防の高さ を格子の境界に与え，越流公式で流れを表現した。 また， 荒子川と中川運河の各河口には水門が設置され，小河川 の水位を調節するためのポンプ所が存在する．本解析で は，各ポンプ所の排水能力に基づき，小河川の水位が維 持水位を超える場合には，この 2 箇所から汇濫水を排出 した，新堀川は堀川と接続し，堀川は名古屋港と接続す る. したがって, 堀川, 新堀川の大部分は感潮河川であ り，名古屋港の潮位変動の影響を受ける. 本モデルでは このような水理現象も表現している.

\section{（2）下水道システムのモデル化}

下水道内の水理は，満管流れと開水路流れが共存する ので，スロットモデルを考慮した 1 次元不定流モデルを 用いて表す. なお，下水道管線は $10 \mathrm{~m}$ 格子で分割し， 簡単のため, 矩形断面とする.

下水道の解析には, 以下の連続式と運動量方程式を用 いた.

$$
\begin{gathered}
\frac{\partial A_{s}}{\partial t}+\frac{\partial Q_{s}}{\partial x}=0 \\
\frac{\partial Q_{s}}{\partial t}+\frac{\partial U_{s} Q_{s}}{\partial x}=-g A_{s} \frac{\partial\left(h_{s}+z_{b s}\right)}{\partial x}-\frac{g n_{s}^{2} Q_{s}\left|U_{s}\right|}{R_{s}^{4 / 3}}
\end{gathered}
$$

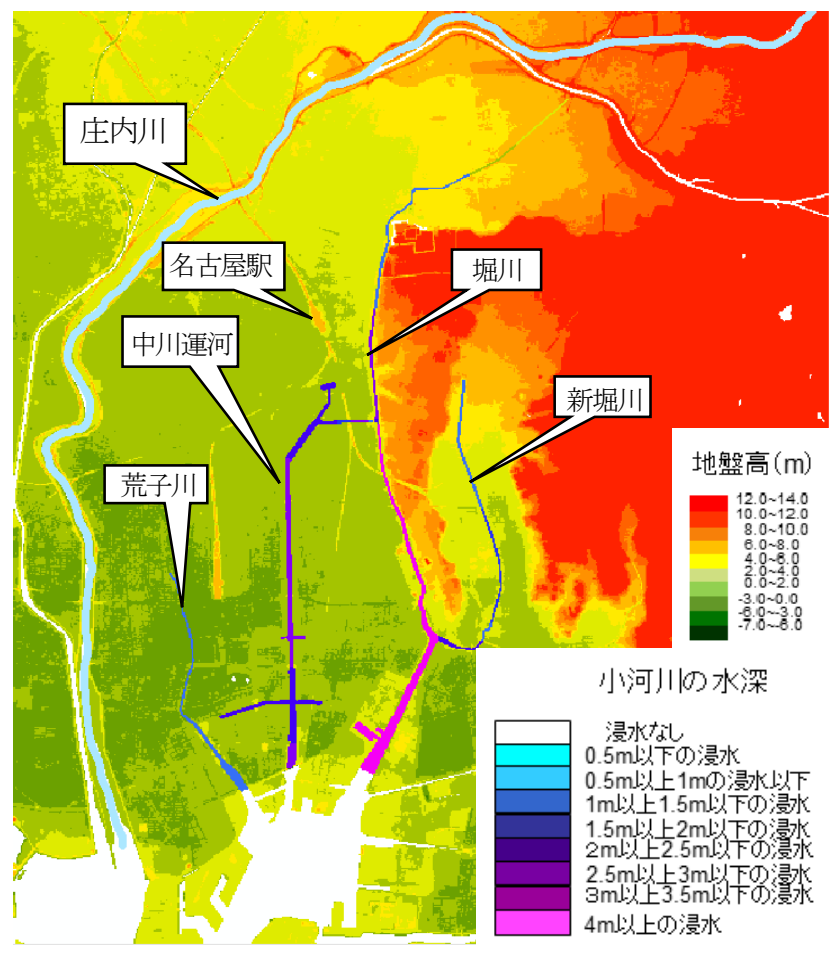

図-1 計算領域

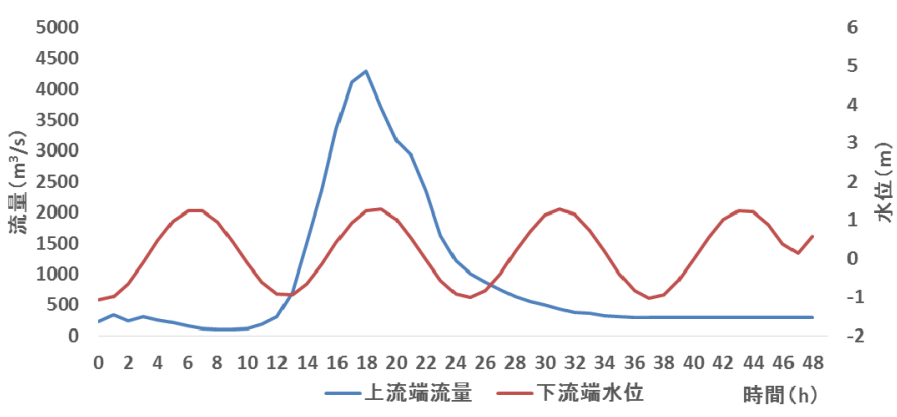

図-2 境界条件

ここで， $A_{s}$ は流水断面積， $Q_{s}$ は流量， $U_{s}$ は流速， $h_{s}$ は水深, $z_{b s}$ は管底高, $\mathrm{g}$ は重力加速度, $n_{s}$ はマニン グ粗度係数, $R_{s}$ は径深である.

マンホールの水理現象は以下の式を用いる.

$$
A_{m} \frac{\partial h_{m}}{\partial t}=\sum Q_{s}+Q_{i n m}-Q_{\text {outm }}
$$

ここで, $A_{m}$ はマンホールの面積, $h_{m}$ はマンホールの 水深, $Q_{o u t m}$ はポンプの排水流量, $Q_{\text {inm }}$ は汇濫域から下 水道への落ち込み流量である. また, $Q_{i n m}=K L h \sqrt{g h}$. Lはマンホールの周長, $\mathrm{h}$ はその対応する地表面の浸水 深であり，マンホールが満水となる場合は氾濫水が落ち 込まないとしている. また，マンホールから地表面に噴 出した水量から単位面積の変化量を求めて, 対応する地 表面の浸水深を補正し, その対応するマンホールと下水 道管渠の水深も補正する.

図-5に示す下水管の余水吐で河川へ自然排水され, 図 中の該当箇所でポンプ排水が存在する. 本研究では，余 
水吐の流量を(2)式を用いて求め, ポンプ箇所では最大 流量を考慮して，その流量を河川格子へ受け渡している. なお，ポンプは破堤が生じた場合も稼働するとした。

\section{3. 解析条件}

本研究では，庄内川の破堤による浸水汇濫を対象とす る. 庄内川上流端流量には計画高水流量を想定し，2011 年 9 月 19 日 20 時 21 日 8 時の庄内川志段味と矢田川瀬 古の流量の合算値の 1.3 倍を洪水流量（ピーク流量 : $\left.4400 \mathrm{~m}^{3} / \mathrm{s}\right)$ として与えた. また, 河川の下流端水位には 当時の名古屋港潮位を与えた. 上流端流量のピーク時間

（計算開始後 19 時間）と名古屋港の大潮の最大潮位時 間を合わせ，ピーク時間に $100 \mathrm{~m}$ 幅で河口から $15 \mathrm{~km}$ 地 点の左岸側の堤防が破堤する。破堤は破堤箇所の堤防天 端が堤内地の地盤高に置き換わることで表現した.

中川運河と荒子川では, 平常時水位が T.P-1.212m と T.P-2.71mであり，維持水位（T.P-1.012m と T.P-2.11m）を 超える場合は河口ポンプ所が一定流量 $\left(15 \mathrm{~m}^{3} / \mathrm{s}\right.$ と $\left.59.3 \mathrm{~m}^{3} / \mathrm{s}\right)$ で排水する.

下水道は管径 $100 \mathrm{~mm}$ 以上のものを対象とし，余水吐 およびポンプ施設により周辺の河川へ排水される. 本研 究では，小河川を陸域格子としたものを「基本」，小河 川の水理を考慮したものを「小河川考慮」，小河川と下 水道の水理を考慮したものを「下水道考慮」と記した.

\section{4. 解析結果および考察}

\section{（1）地表の浸水特性}

まず，基本と小河川考慮の比較を行うことで，小河川 を考慮することの氾濫計算上の特徵を明らかにする．図 -3 に基本と小河川考慮の浸水深の分布を, 図-4 に最大浸 水深の分布を示す．まず，図-3では，破堤後の浸水の様 子がみてとれ，JR 盛土構造物に沿って流下した後で, 中川運河を越えて浸水が拡がっていることが分かる。一 方, 小河川考慮の場合, 初期の浸水の様子は基本のもの と変わらないが，越流し河川へ流入し，河川水位が大き くなって陸域へ汇濫することから，基本よりも小さな浸 水の広がりとなっている. また，その結果を受けて，西 側の汇濫水の拡がりも小さなものとなっている.つぎに, 図-4の最大浸水深の分布をみれば，破堤箇所から中川運 河までの地域には浸水深の違いはみられないが，破堤箇 所から離れた地域には浸水深の違いがみられ，基本の結 果は浸水深を大きく見積もる結果となっている.

つぎに，下水道考慮における浸水深の時間変化を図-5 に，最大浸水深の分布を図-6に示寸，なお，図-5には， 同時刻の下水道の満管率（下水道管の水深と管径の割合, 満管が 100\%) も記している.これらの図から，下水道 が有る場合の浸水の様子が理解できる，22h（破堤から 3 時間後）の様子をみると, 下水道内の水の伝搬は地上 の浸水よりも遠方に拡がっていることが分かり, その後 の地上と下水道内の氾濫水の移動の様子も解析できてい る. 現在のところ, 定量的な妥当性検証が十分で無いが, 定性的には妥当な結果と考えている. また, 図-6に下水 道考慮における最大浸水深の分布を示寸. 本図と図4の 比較から, 下水道考慮の最大浸水深の結果は, 河川考慮 の場合と同様であることが分かる.

より詳細に検討するために, 図-7 は最大浸水深を対象 に，小河川考慮の結果から基本の結果を引いて表した. 本図から，破堤箇所近傍では，差は生じていないが，遠 くなれば相対水深が負值（減少する）の結果となってお り, 逆に, 川を伝って浸水が生じた箇所では正值（増加 する）の結果となった．紙面の都合上，下水道考慮の場 合を示すことが出来なかったが，破堤箇所近傍でもわず かながら負值がみられ，その值は $5 \mathrm{~cm}$ 程度であった。

また，地上の汇濫水量の時間変化を図-8 に示寸. 本図 から氾濫初期の様子は，3つのケースとも同様の傾向を 示しているが，浸水が河川へ到達した時点から 3 つに分 かれ，基本の条件よりも小河川考慮の方が河川一流下寸 ることから汇濫水量は低下し, 河川への排水機能を持つ, 下水道を考慮した方がさらに氾濫水量は低下寸ることが 分かる.これらは，定性的な観点から妥当な結果である. さらに, 図-9には, 計算終了時の地表面の氾濫水量と地 下空間（地下街・地下鉄駅と地下鉄線路）の浸水水量を 示している. 本図から, 計算終了時は地表の氾濫水量に は変化がみられるが，地下空間の水量は同程度であるこ とが分かる.これは，本解析条件の場合大きな水深の発 生場所は大きく変化せず, したがって, 地下空間の汇濫 水量が大きく変化していないことが推察される.

\section{（2）地下鉄の浸水特性}

本研究は，大都市の浸水を扱っており，その中で，地 下街や地下鉄などの地下空間の浸水を扱っている点に特 徵がある. なお，ここでは地下空間における排水は考慮 しておらず, 本解析条件における地下浸水（特に, 地下 鉄線路の浸水状況）について考察を行う.

図-9に示した，それぞれの解析条件における計算終了 時の地下空間の汇濫水量は同程度であった. 図-10に, 解析条件における計算終了時の地下鉄の浸水の様子を示 寸.これらの図からも同様の浸水状況であることが分か る. 地下空間の入口が多数存在する地域に大量の汇濫水 が流れ込むことが地下空間の汇濫水量を増大させる. 本 研究の条件では, 名古屋駅周辺における汇濫水の地下空 間への流入が大きいものと考えられ，その箇所での汇濫 現象に差が生じていないことから, 図-10 の結果に差が 生じなかったと考えられる. 

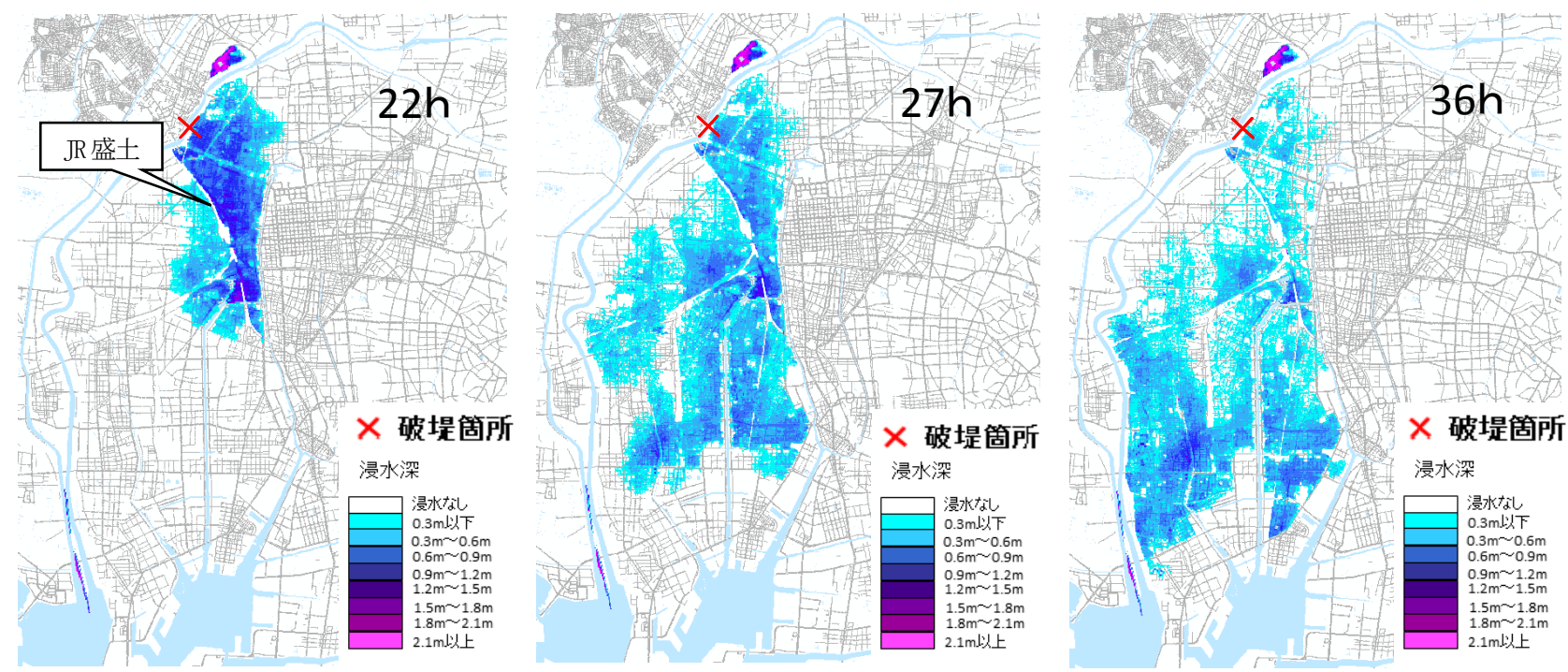

基本
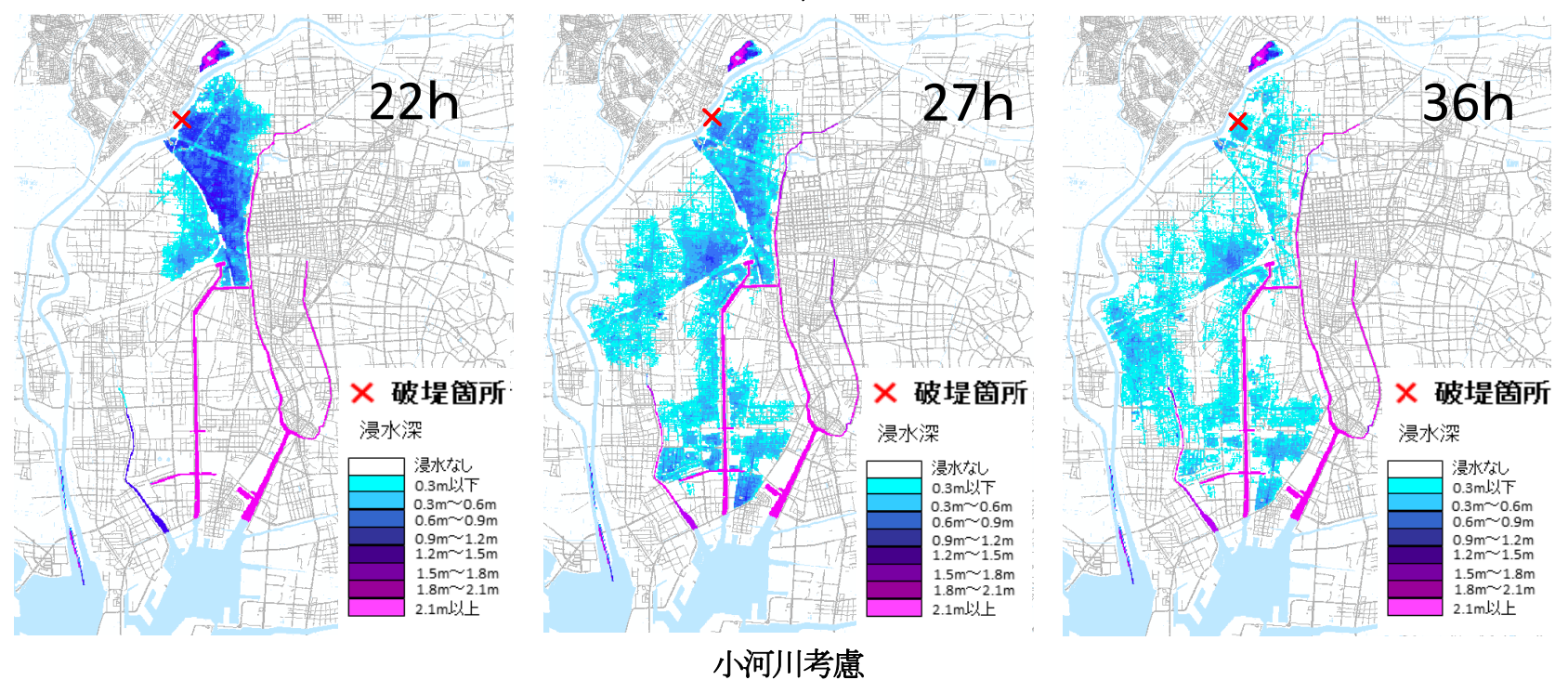

図-3 基本と小河川考慮における浸水深の時間変化
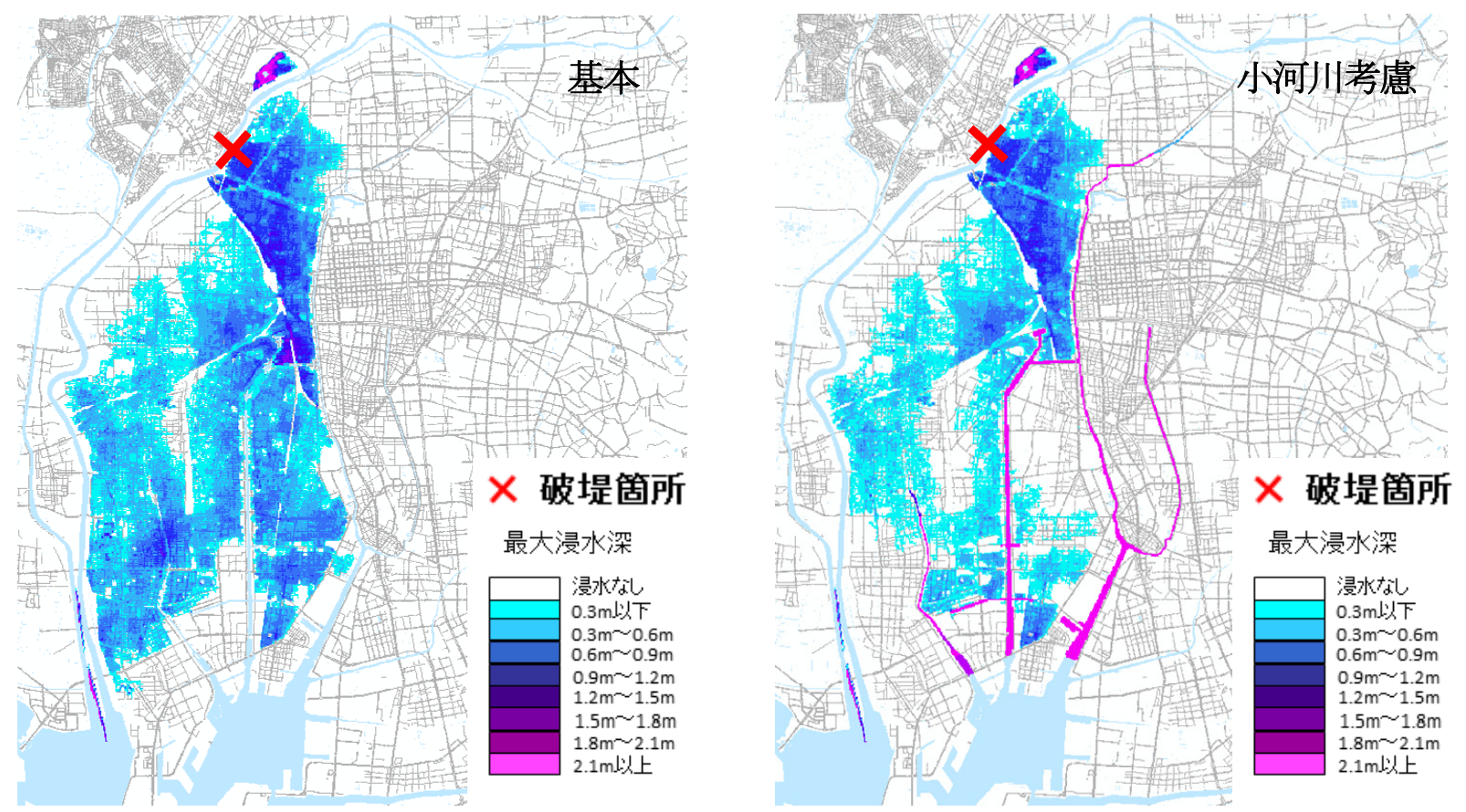

図-4 基本と小河川考慮における最大浸水深 

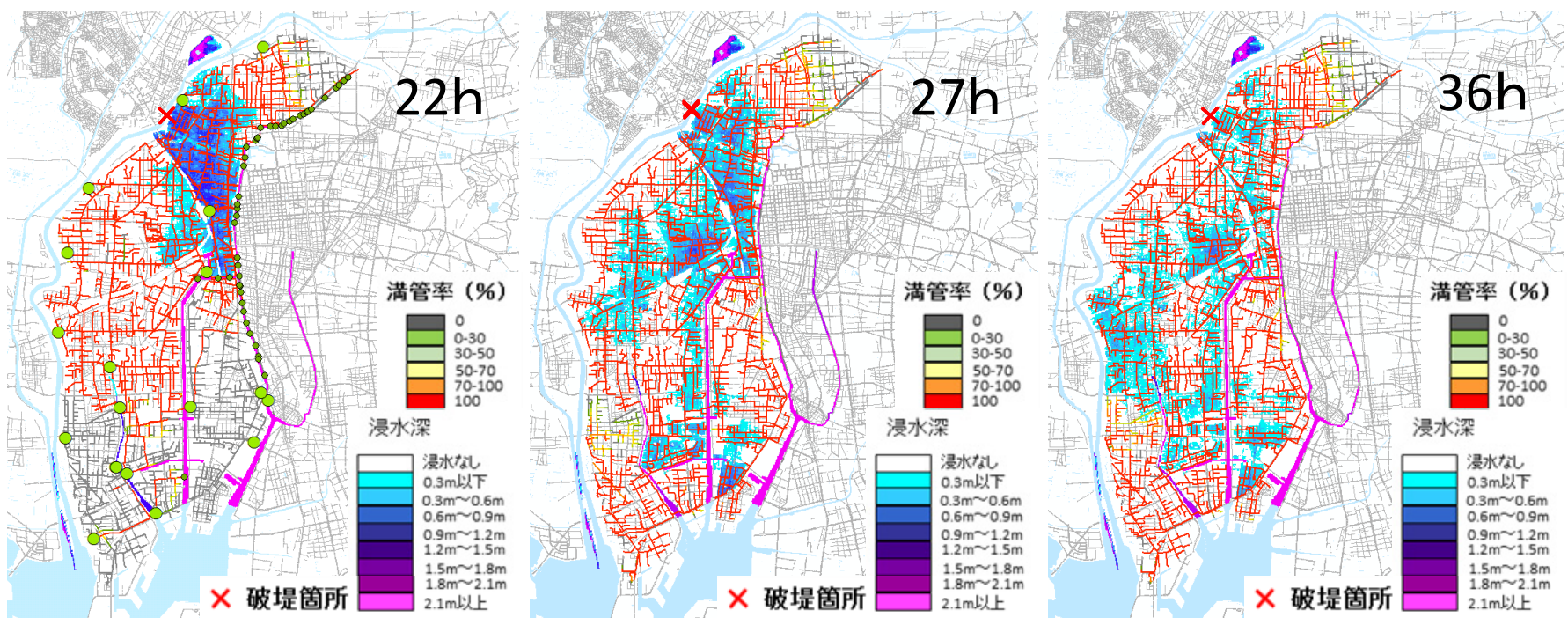

図-5 下水道考慮における浸水深の時間変化下水道管道の満管率

○は排水ポンプ箇所，○は余水吐きの位置

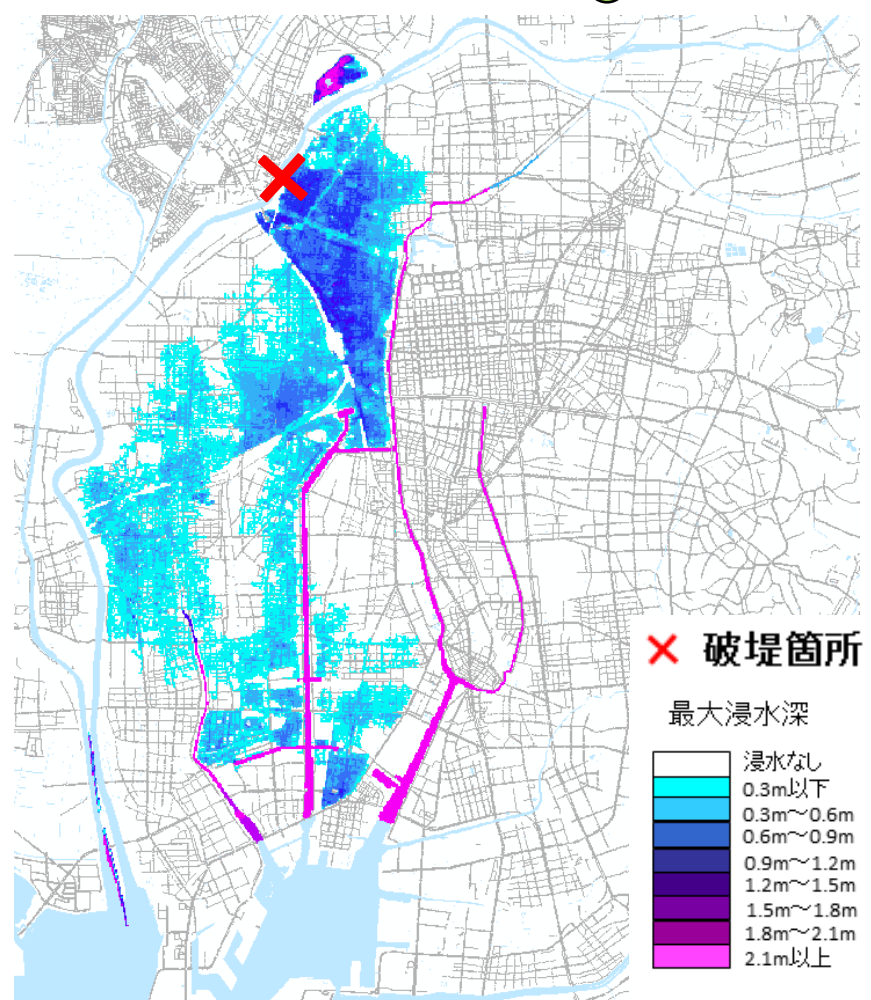

図-6 下水道考慮における最大浸水深

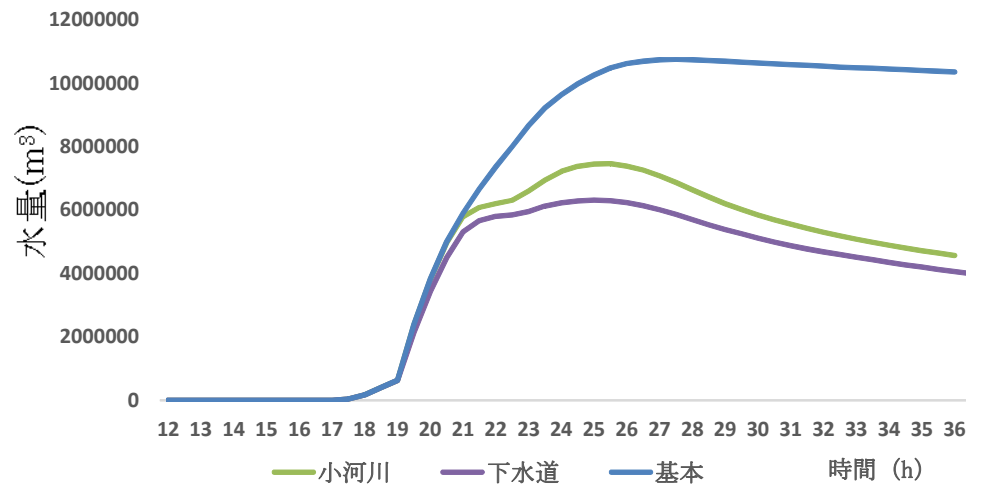

図-8 地表面浸水量の時間変化

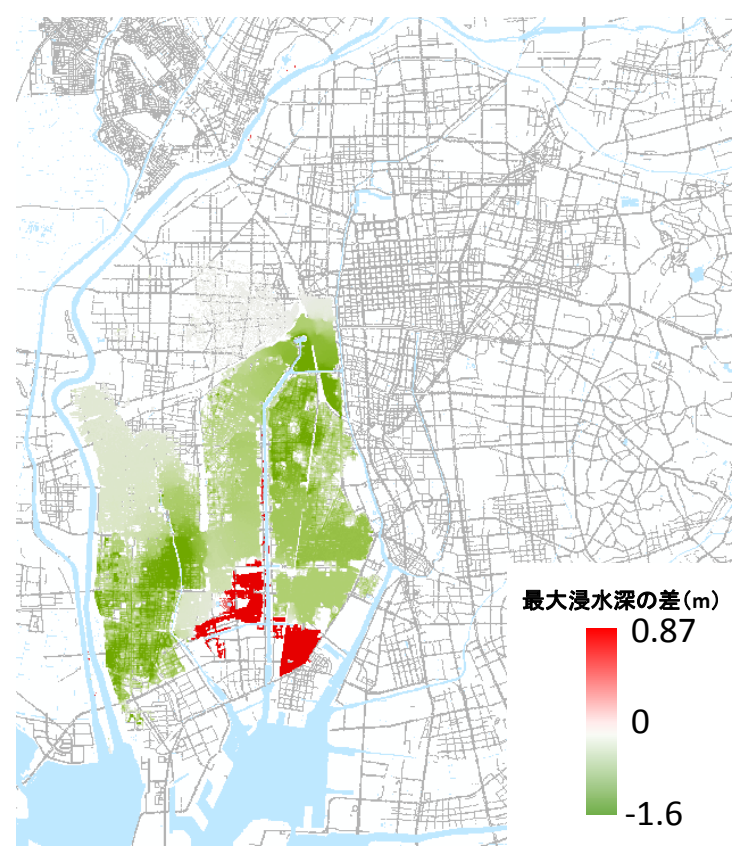

図-7＼cjkstart基本と小河川考慮の最大浸水深の差 $\left(\mathrm{m}^{3}\right)$

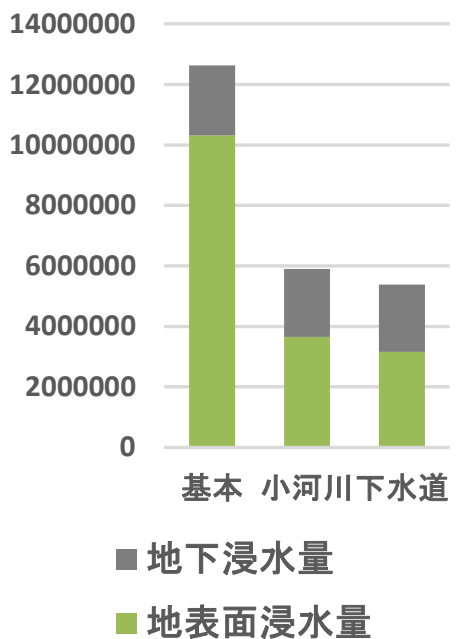

図-9 計算終了時の地下と地表面の総浸水量 


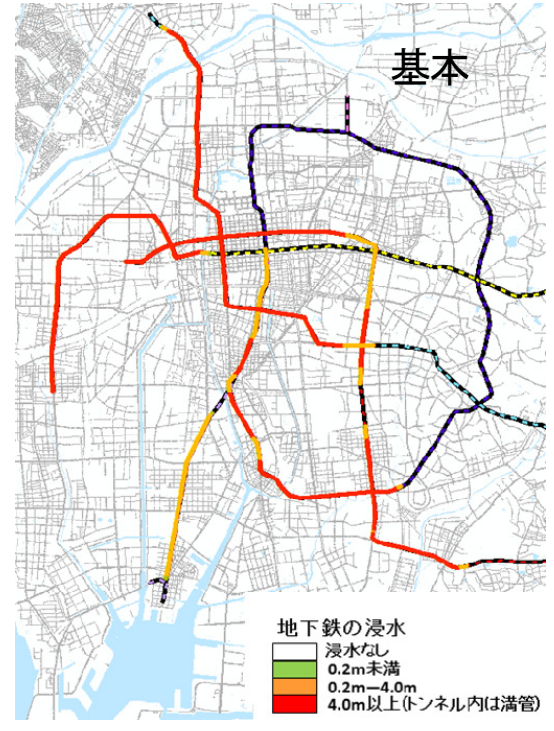

\section{5. おわりに}

本研究では，小河川を考慮しない洪水破堤による汇濫 解析を基礎とし，小河川考慮の場合，小河川を含めた下 水道考慮の場合の計算結果からモデルの特性を検討した 本研究で得られた成果をまとめれば以下のとおりである. 1）小河川を考慮する場合，破堤箇所から小河川までの 浸水の広がりは変わりなかったが，河川への流入により 氾濫水の拡がりが低下し, 川を渡って新たな浸水が生じ ることが示された。

2）小河川を含めて下水道を考慮する場合，小河川を含 めた場合と同様の結果となったが，排水が早く進む特徵 も示されていた.

3）地下空間への浸水量には，大規模な浸水深が大きく 影響するので，それぞれの取り扱いにおける差異は小さ い結果となった. しかし，これらの結果は小河川や下水 道の配置にも影響を受けると考える.

謝辞 : 本研究は文部科学省委託事業気候変動リスク情報 創生プログラム「課題対応型の精密な影響評価」のもと で行われたことを記す。

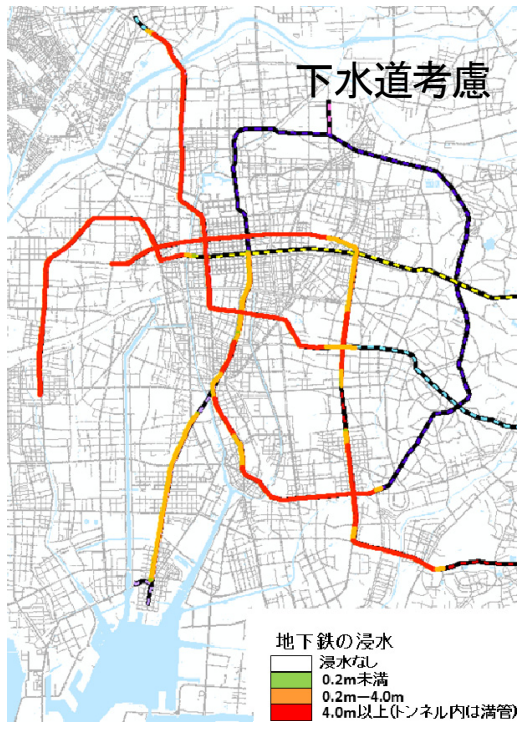

地下鉄の浸水 浸水斻 0.2

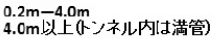

$0.2 \mathrm{~m}-4.0 \mathrm{~m}$
$4.0 \mathrm{~m}$ 上

図-10 地下鉄の浸水状況

\section{参考文献}

1）毎日新聞ホームページ，台風10号 北海道にも被害 南富良 野町で空知川堤防決壊http:// mainichi. jp/articles/20160831 /k00/00e/040/215000c（2015年9月27日確認）

2) 関根正人, 小林香野: 荒川決壊を想定した東京東部低 平地の大規模浸水プロセスに関する数值予測, 土木学 会第 71 回年次学術講演会, II -44:, 2016.

3) 浅野統弘, 尾崎平, 石垣泰輔, 戸田圭一: 南海トラフ 巨大地震による津波来襲時の大規模地下空間の浸水予 測, 土木学会論文集 B1 (水工学)，Vol.70, No.4, I_1435-I_1440, 2014.

4) 武田誠, 島田嘉樹, 川池健司, 松尾直規 : 庄内川の想定破堤 汇濫による地下空間への流入水量の検討, 第 20 回地下空間シ ンポジウム, pp155-164, 2015.

5) 武田 誠・西田貢士郎・村瀬将隆・ 川池健司・松尾直規 : 地 下鉄を考慮した都市の浸水解析, 第 21 回地下空間シンポジウ ム, 2016.

(2016.9. 30 受付)

\section{THE INFLUENCE OF SMALL RIVERS AND SEWER SYSTEM ON THE LARGE SCALE INUNDATIO DUE TO DIKE BREAK}

\section{Makoto TAKEDA, Yunfei XUAN, Masataka MURASE, Yusuke NAKAJIMA, Kenji KAWAIKE and Naoki MATSUO}

Small rivers and sewer system in urban area often are ignored in the analysis of large scale inundation. In this study, the influence of small rivers and sewer system made clarify by using numerical analysis. In comparison with and without small rivers, Although the appearance of the inundation near dike break point was not change significantly, the difference in spread way and inundated region occurred. Moreover, inundation water volume of the underground space has not changed significantly. Therefore, there was no difference of models concerning the inundation situation of subway line. 